\title{
Ultrastructural features of preovulatory oocyte maturation in superovulated cattle
}

\author{
P. Hyttel, H. Callesen* and T. Greve*
}

\begin{abstract}
Department of Anatomy and ${ }^{*}$ Institute for Animal Reproduction, Royal Veterinary and Agricultural University, Bülowsvej 13, DK-1870 Frederiksberg C, Denmark
\end{abstract}

\begin{abstract}
Summary. Cows and heifers were induced to superovulate by treatment with PMSG or FSH. The ultrastructural features of the oocytes were related to the time of the LH peak and the progesterone/oestradiol-17 $\beta$ ratios in the follicular fluid.

At $0-2 \mathrm{~h}$ after the LH peak the perivitelline space developed; at 9-12 $\mathrm{h}$ there was disconnection of the junctions between cumulus cell projections and oolemma, and the concomitant breakdown of the oocyte nucleus; at $\sim 15 \mathrm{~h}$ there were spatial rearrangements in the ooplasm of (a) mitochondrial clusters from a peripheral to an even distribution and (b) vesicles from an even distribution to a more central location; at $\sim 19 \mathrm{~h}$ there was abstriction of the first polar body with dislocation of mitochondrial clusters and vesicles towards the site of polar body formation; at 21-22 $\mathrm{h}$ there was migration of cortical granules to solitary positions along the oolemma and decrease in the sizes of Golgi complexes and, on some occasions, the smooth endoplasmic reticulum. These ultrastructural changes were accompanied by an increase in progesterone/oestradiol ratios in the follicular fluids.

It is concluded that preovulatory oocyte maturation in gonadotrophin-stimulated cattle comprises nuclear as well as cytoplasmic changes accompanied by steroidogenic changes in the follicle, each of which are closely related to the time of the LH peak. However, some variation existed between animals, between follicular and oocyte maturation and even within oocytes between nuclear and cytoplasmic maturation.
\end{abstract}

\section{Introduction}

In the preovulatory follicle and oocyte a number of hormonal, chromosomal and morphological changes signal the approaching ovulation. These changes are closely related to and presumably initiated by the preovulatory LH surge (Moor \& Warnes, 1979).

The steroid pattern in the follicular fluid in cows and heifers is characterized by a shift from being oestradiol dominated before the LH surge to an increasing dominance of progesterone after the surge as demonstrated in cattle not treated with exogenous gonadotrophins (unstimulated) (Ireland \& Roche, 1983; Dieleman, Kruip, Fontijne, de Jong \& van der Weyden, 1983) as well as in gonadotrophin-stimulated cattle (Callesen, Greve \& Hyttel, 1984). Similar steroidogenic changes are reported for women (Bomsel-Helmreich et al., 1979).

The preovulatory maturation of the oocyte comprises nuclear as well as cytoplasmic changes. Ultrastructural studies of these processes have been conducted by Flemming \& Saacke (1972) and Kruip, Cran, van Beneden \& Dieleman (1983) in unstimulated cattle; Kruip et al. (1983) related the morphological changes to the LH surge. However, there is a great need for obtaining information on the relations between the LH surge, the steroidogenic capacity of the follicle and the ultrastructural development of the oocyte during the preovulatory maturation in gonadotrophin stimulated cattle because of the widespread use of superovulation in cattle and the highly unpredictable results of the superovulatory treatments. 
The objectives of the present study were (1) to provide an ultrastructural description of the bovine oocyte and (2) to relate the ultrastructural features to the time of the $\mathrm{LH}$ peak and to the progesterone/oestradiol-17 $\beta$ ratios in the follicular fluid in cattle stimulated with exogenous gonadotrophins.

\section{Materials and Methods}

Animal treatment and follicular aspiration. Oestrus in 24 dairy cows or heifers (Jersey or Danish Black and White) was synchronized with two injections of $0.5 \mathrm{mg}$ cloprostenol (Estrumate: Lundbeck and Co., Valby, Denmark) 11 days apart. In the mid-luteal phase of the following cycle the animals were given a single injection of 1500-3000 i.u. PMSG (Antex: LEO Pharmaceuticals, Ballerup, Denmark) $(\mathrm{N}=16)$ or P.FSH (Burns Biotec., Omaha, NE, USA) $(\mathrm{N}=8)$ twice daily for 5 days or until ovariectomy in decreasing doses: $5 / 5 \mathrm{mg}, 4 / 4 \mathrm{mg}, 3 / 3 \mathrm{mg}, 2 / 2 \mathrm{mg}, 1 / 1 \mathrm{mg}$, respectively. At $48-72 \mathrm{~h}$ after the initial injection the animals were injected with cloprostenol to cause luteal regression. Blood samples were obtained every $4 \mathrm{~h}$ after cloprostenol treatment for $\mathrm{LH}$ analyses. At the 1st, 2nd or 3rd day after cloprostenol treatment, the animals were ovariectomized via laparotomy or a transvaginal incision using either local or epidural analgesia. The ovaries were visually inspected for the presence of ovulations and corpora lutea. Within $30 \mathrm{~min}$ after ovariectomy all visible antral follicles were aspirated. Only follicles in which the follicular fluid exceeded $0.2 \mathrm{ml}$ in volume ( $\sim 8 \mathrm{~mm}$ in diameter (McNatty, Moore Smith, Osathanondh \& Ryan, 1979)) were randomly selected for this study. By means of stereomicroscopy the cumulus-oocyte complex was isolated from the follicular fluid which was centrifuged, decanted and stored at $-20^{\circ} \mathrm{C}$ until progesterone and oestradiol-17 $\beta$ analyses were performed.

Hormone assays. LH in plasma was measured using a radioimmunoassay (Stupnicki \& Madej, 1976) modified as described by Jensen, Greve, Madej \& Edqvist (1982). Antiserum against bovine LH (a-bLH/R7) was produced and characterized by Stupnicki \& Madej (1976). The sensitivity of the assay was $1 \mathrm{ng} / \mathrm{ml}$ plasma. The intra- and inter-assay coefficients of variation were $<12$ and $<10 \%$, respectively. An LH surge was defined as an increase of more than $50 \%$ above the basal level calculated as the mean of 3 sequential $\mathrm{LH}$ measurements. The $\mathrm{LH}$ peak was defined as the highest $\mathrm{LH}$ concentration during the surge.

Progesterone in follicular fluid was determined by a radioimmunoassay (Hoffmann, Kyrein \& Ender, 1973) modified as described by Solti, Greve \& Koefoed-Johnsen (1978). The progesterone antiserum was produced in rabbits against $11 \alpha$-hydroxyprogesterone-hemisuccinate-BSA. The antiserum crossreacts $<0.2 \%$ with various tested steroids. The sensitivity of the assay was $0.5 \mathrm{ng} / \mathrm{ml}$ follicular fluid. The intra- and inter-assay coefficients of variation were $<7$ and $<11 \%$, respectively. The accuracy of the assay was satisfactory, as the concentration of progesterone measured was independent of the volume of follicular fluid, and there was a high correlation $(r=0.99)$ between added and measured progesterone.

Oestradiol-17 $\beta$ in follicular fluid was determined by radioimmunoassay using a modification without chromatography of the method initially described by Emment, Collins \& Sommerville (1972). The antiserum was produced in rabbits against 6-keto-oestradiol coupled to BSA via 6-O-carboxymethyl-oxime. The antiserum cross-reacts with oestrone $(11 \cdot 1 \%)$, 16-epi-oestriol $(10 \cdot 3 \%), 2$-hydroxyoestradiol $(2 \cdot 5 \%), 16$-keto-oestradiol $(2 \cdot 1 \%)$ and $<0.4 \%$ with other steroids tested (B. Svenstrup, personal communication). The sensitivity of the assay was $12 \mathrm{pg} / \mathrm{ml}$ follicular fluid. The intra- and inter-assay coefficients of variation were $<11$ and $<12 \%$, respectively. The accuracy of the assay was satisfactory, as the concentration of oestradiol-17 $\beta$ measured was independent of the volume of follicular fluid, and there was a high correlation $(r=0.99)$ between added and measured oestradiol in follicular fluid.

Tissue preparation. Cumulus-oocyte complexes (52) were fixed in $3 \%$ glutaraldehyde in $0 \cdot 1$ M-phosphate buffer for $1 \mathrm{~h}$ at $4^{\circ} \mathrm{C}$ and post-fixed in $1 \% \mathrm{OsO}_{4}$ in $0.1 \mathrm{M}$-phosphate buffer for $1 \mathrm{~h}$ at 
$4^{\circ} \mathrm{C}$. Subsequently, they were washed in distilled water and block-stained with $0 \cdot 5 \%$ uranyl acetate, dehydrated and embedded in Epon following standard procedures and, finally, serially sectioned in alternating semithin and ultrathin sections. Ultrathin sections were always prepared when an oocyte nucleus, i.e. a germinal vesicle, condensed chromatin configurations, or a polar body appeared in the semithin sections and/or at the equatorial plane of the oocyte. The semithin sections were stained with toluidine blue while the ultrathin sections were stained with uranyl acetate and lead citrate and examined on a JEM-1200 EX (Jeol, Tokyo, Japan).

\section{Results}

\section{Nuclear maturation and follicular steroids}

Based on structural features the aspirated oocytes were divided into the following types: those that had an intact rounded nucleus, i.e. germinal vesicle (I), those that had neither a rounded nucleus nor a polar body (II), and those that had a polar body (III).

Table 1 indicates the defined grouping of the oocytes and the progesterone/oestradiol ratios of the respective follicles relative to the $\mathrm{LH}$ peak in each animal. A general pattern of preovulatory

Table 1. The structural grouping of isolated oocytes and progesterone/oestradiol ratios of the respective follicles listed according to the time from the $\mathrm{LH}$ peak to the ovariectomy in superovulated cattle

\begin{tabular}{|c|c|c|c|c|}
\hline $\begin{array}{l}\text { No. of } \\
\text { animal }\end{array}$ & $\begin{array}{l}\text { Time from } \\
\text { LH peak }\end{array}$ & $\begin{array}{l}\text { Type of } \\
\text { oocyte* }\end{array}$ & \multicolumn{2}{|c|}{$\begin{array}{l}\text { Progesterone/oestradiol } \\
\text { ratio (mean } \pm \text { s.e.m.) }\end{array}$} \\
\hline $1 \S$ & No LH surge & I, II, II, II, & \multicolumn{2}{|c|}{$656 \cdot 69+307 \cdot 22$} \\
\hline 2 & No LH surge & I & \multicolumn{2}{|l|}{0.13} \\
\hline 3 & No LH surge & $\mathrm{I}, \mathrm{I}$ & $0.06 \pm$ & 0.01 \\
\hline $4 \S$ & 0 & I, I & $0.07 \pm$ & 0.01 \\
\hline 5 & 0 & $\mathrm{I}, \mathrm{I}$ & $0 \cdot 10 \pm$ & 0.03 \\
\hline 6 & 2 & I, I & $0 \cdot 10 \pm$ & 0.01 \\
\hline 7 & 6 & I & \multicolumn{2}{|c|}{$0.13^{-}$} \\
\hline 8 & 9 & $\mathrm{I}, \mathrm{I}, \mathrm{II} \dagger$ & \multicolumn{2}{|c|}{$0.38 \pm 0.03$} \\
\hline 9 & 9 & II, II, III & & $0 \cdot 17$ \\
\hline $10 \pi$ & 10 & II & \multicolumn{2}{|c|}{$\begin{array}{l}0.08 \pm 0.17 \\
0.39\end{array}$} \\
\hline 11 & 10 & II $\dagger$, II, II, II & \multicolumn{2}{|c|}{$0.47 \pm 0.05$} \\
\hline 12 & 12 & II, II & $0.39 \pm$ & 0.00 \\
\hline 13 & 12 & II & \multicolumn{2}{|c|}{0.62} \\
\hline 14 & 14 & II, II & \multicolumn{2}{|c|}{$0.68+0.07$} \\
\hline 15 & 15 & II, II, II & $1.04 \pm$ & $0 \cdot 10$ \\
\hline 16 & 19 & II & \multicolumn{2}{|l|}{$4.78^{-}$} \\
\hline 17 & 19 & I, I, II & \multicolumn{2}{|c|}{$2.26 \pm 0.12$} \\
\hline 18 & 21 & II & \multicolumn{2}{|l|}{$4 \cdot 22$} \\
\hline 19 & 21 & III & \multicolumn{2}{|l|}{$5 \cdot 40$} \\
\hline 20 & 22 & III, III & \multicolumn{2}{|c|}{$20 \cdot 44 \pm 7 \cdot 17$} \\
\hline 21 & 23 & III, III & \multirow{2}{*}{\multicolumn{2}{|c|}{$\begin{array}{r}2.98 \pm \quad 0.71 \\
6.67\end{array}$}} \\
\hline 229 & 26 & II & & \\
\hline 239 & 26 & II, III, III, III & \multicolumn{2}{|c|}{$136 \cdot 33+40 \cdot 18$} \\
\hline 24 & 27 & III & \multicolumn{2}{|l|}{$7.95^{-}$} \\
\hline
\end{tabular}

*I, intact spherical oocyte nucleus present;

II, neither intact spherical oocyte nucleus nor polar body present:

II $\dagger$, oocyte nucleus in the process of breaking down;

II + , first polar body in the process of being abstricted;

III, first polar body present.

\$-4 day-old corpus luteum observed.

TFresh ovulations observed. 


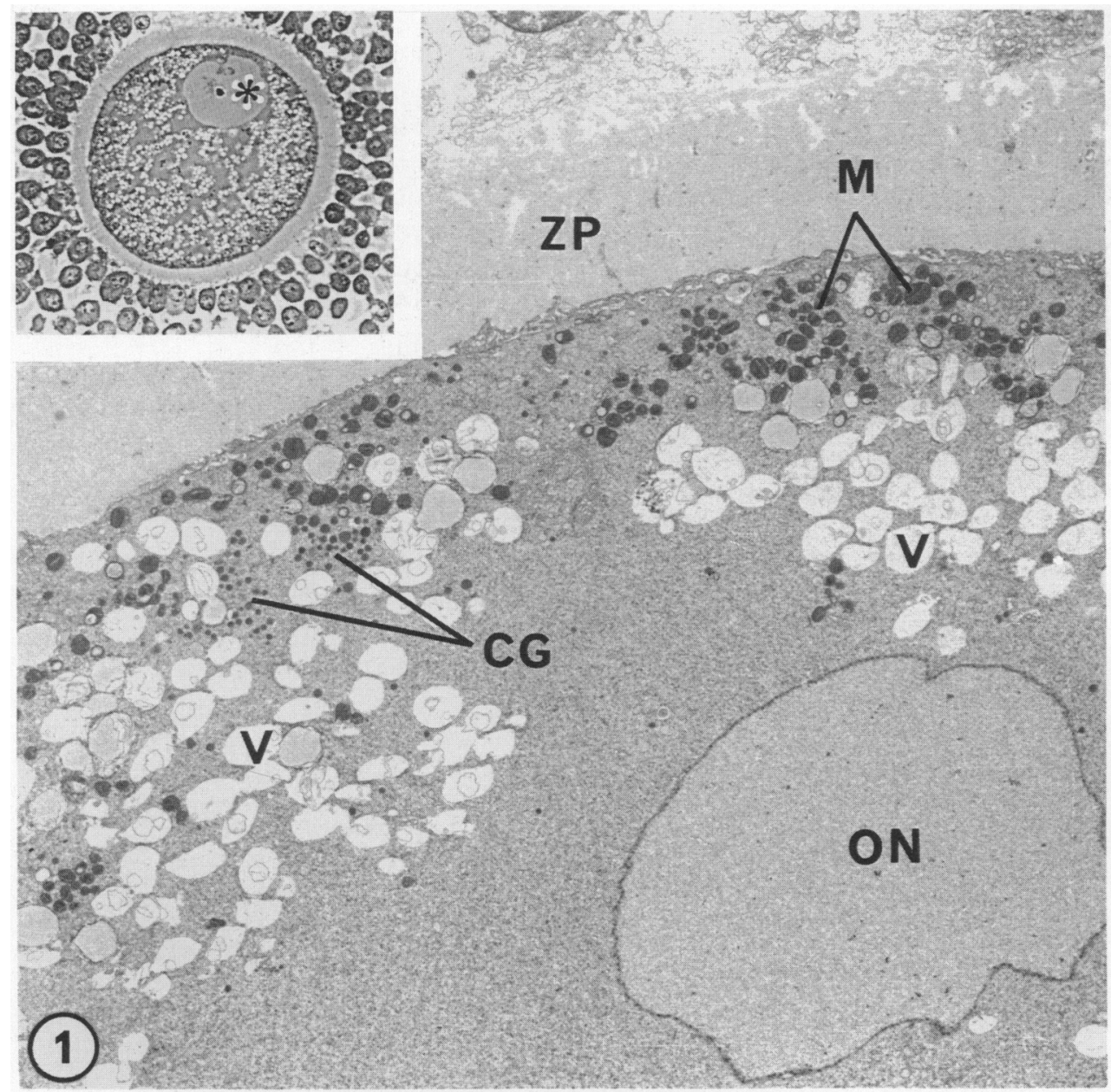

Fig. 1. Part of a type I oocyte showing the zona pellucida (ZP), and in the oocyte the nucleus $(\mathrm{ON})$, vesicles $(\mathrm{V})$, mitochondrial clusters $(\mathrm{M})$ and clusters of cortical granules $(\mathrm{CG})$ are present. $\times 4990$. Inset: A type I oocyte with the eccentric oocyte nucleus $\left({ }^{*}\right) . \times 250$.

nuclear maturation was observed indicating that the oocyte nucleus breakdown occurred about 9-12 $\mathrm{h}$ after the $\mathrm{LH}$ peak and the abstriction of the first polar body occurred $\sim 19 \mathrm{~h}$ after the $\mathrm{LH}$ peak. A parallel pattern was observed in the steroid ratios of the follicular fluids. The ratios were relatively low before and up to $6 \mathrm{~h}$ after the LH peak and increased slightly from 6 to $15 \mathrm{~h}$ and substantially from 15 to $19 \mathrm{~h}$ to higher and more variable values.

Some variation or asynchrony between animals and between follicular and oocyte maturation was noticed. For example the follicles in Animal 1 had very high progesterone/oestradiol ratios and some contained oocytes of type II although no LH surge was detected. With the exception of this animal the progesterone/oestradiol ratios of all follicles studied followed the general pattern within a certain range although some oocytes with asynchronous nuclear maturation were isolated in Animals 9, 17, 22 and 23.

No differences in nuclear maturation and follicular steroids between animals stimulated with PMSG or FSH were noticed. 




Fig. 2. Detail of a type I oocyte showing the relations between vesicles (V), mitochondria (M) and smooth endoplasmic reticulum (SER). $\times 68000$.

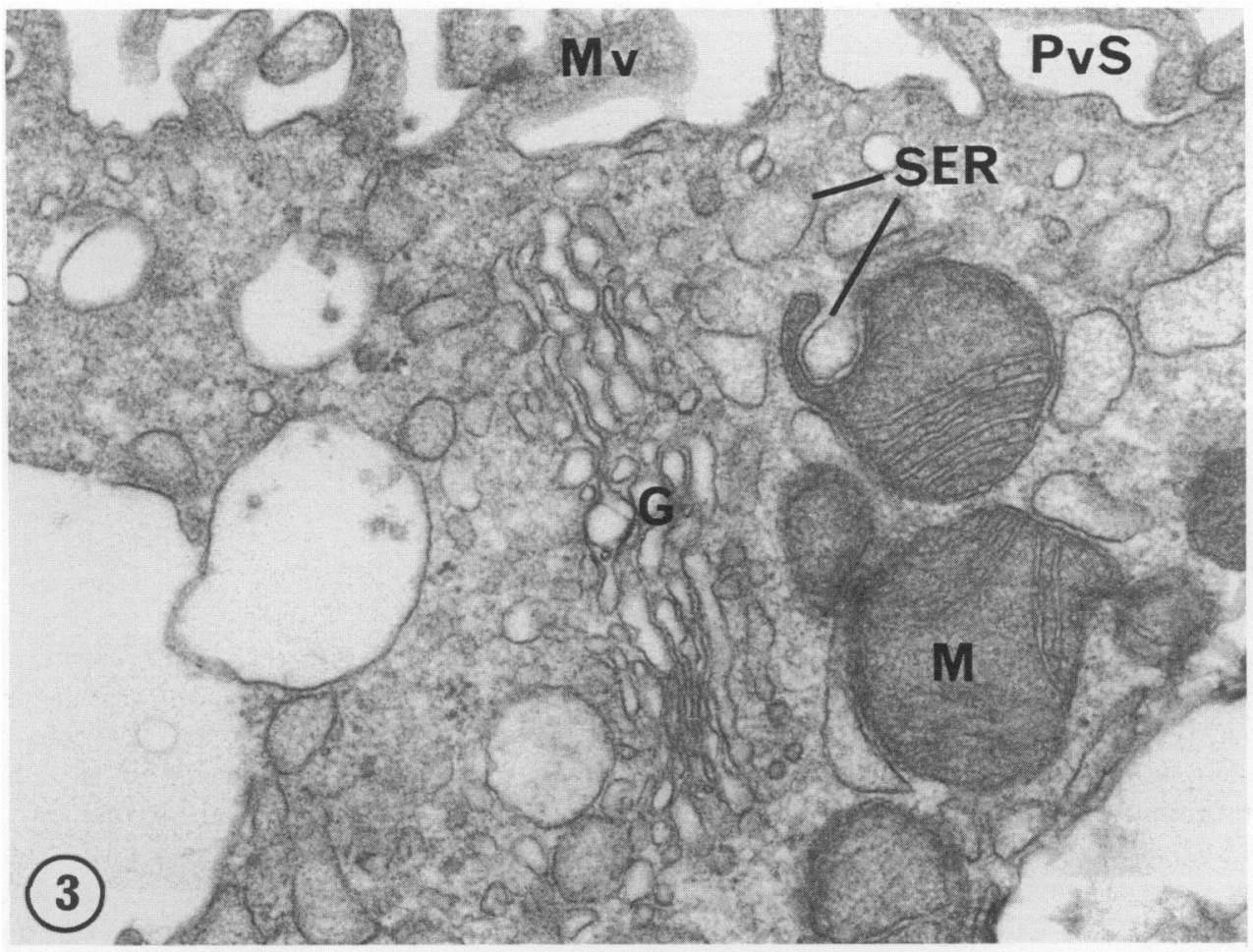

Fig. 3. Detail of a type I oocyte with microvilli (Mv) projecting into the perivitelline space (PvS). In the ooplasm a Golgi complex (G) and mitochondria (M) closely related to the smooth endoplasmic reticulum $($ SER) are present. $\times 100000$. 


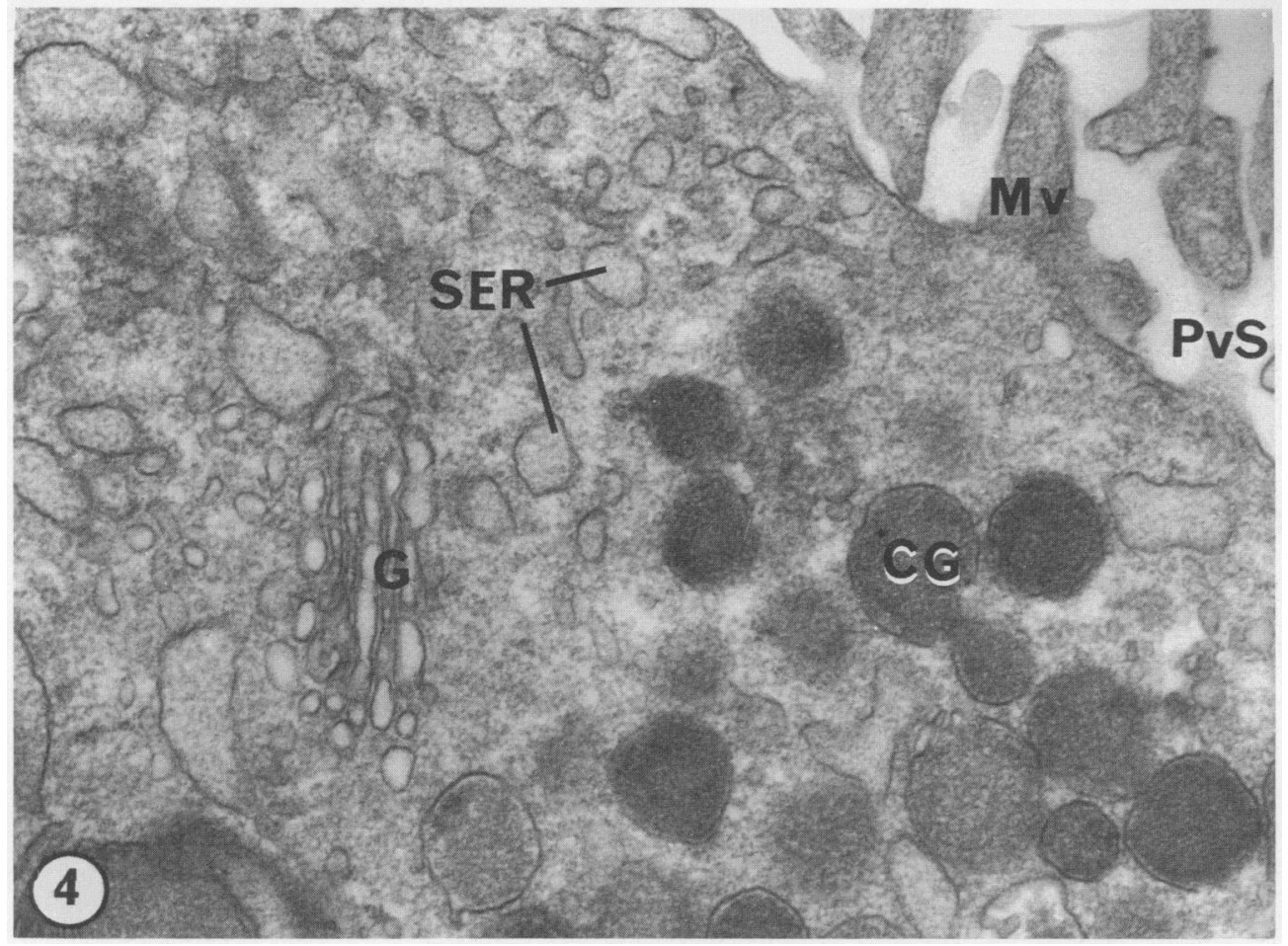

Fig. 4. Detail of a type I oocyte with microvilli $(\mathrm{Mv})$ projecting into the perivitelline space $(\mathrm{PvS})$. In the ooplasm a Golgi complex (G), smooth endoplasmic reticulum (SER) and cortical granules $(\mathrm{CG})$ are present. $\times 100000$.

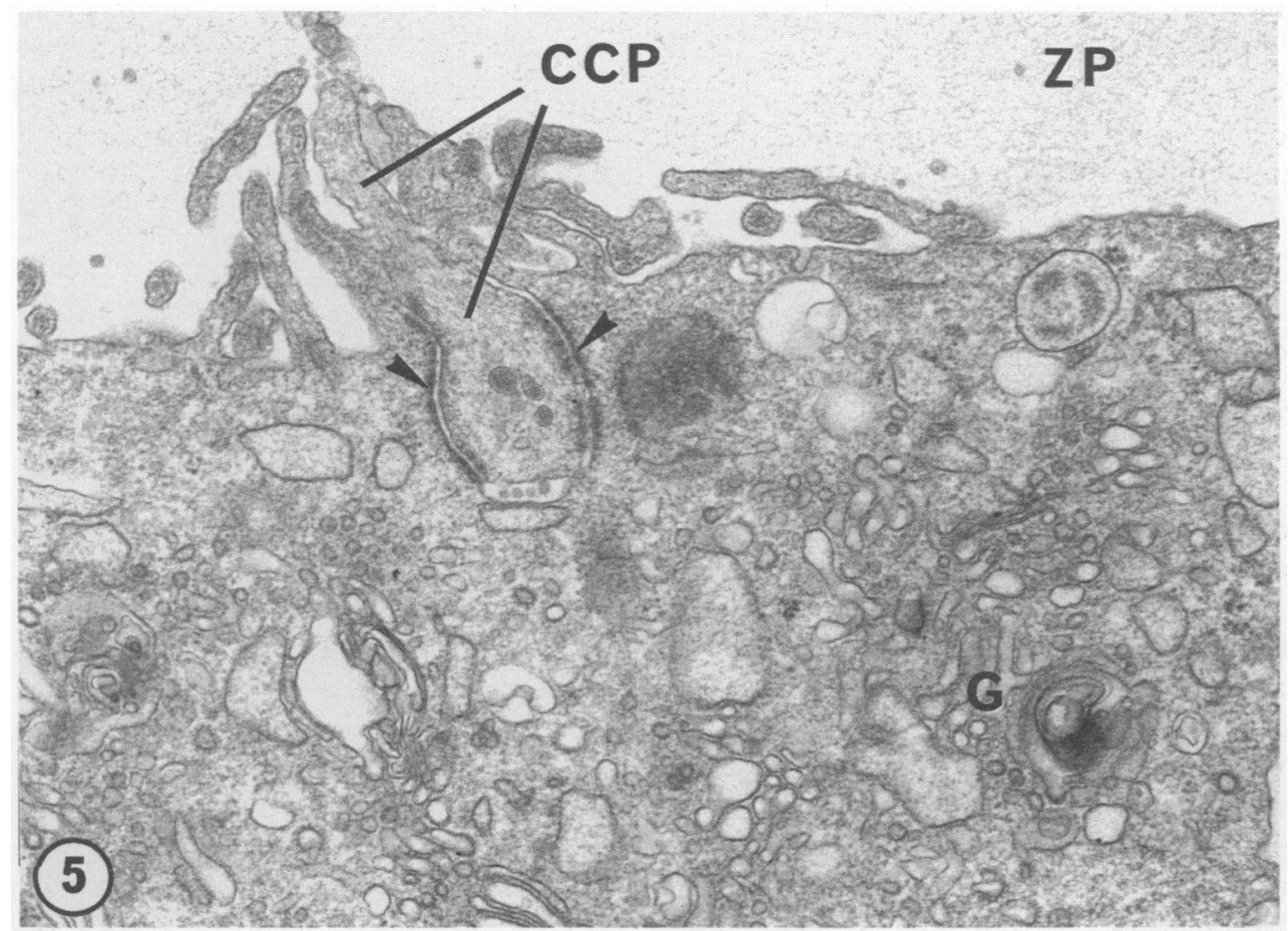

Fig. 5. Detail of type I oocyte showing the zona pellucida $(Z P)$ which is traversed by a cumulus cell projection (CCP), establishing junctions with the oolemma ( $>$ ). In the ooplasm Golgi complexes $(\mathrm{G})$ are present. $\times 68000$. 

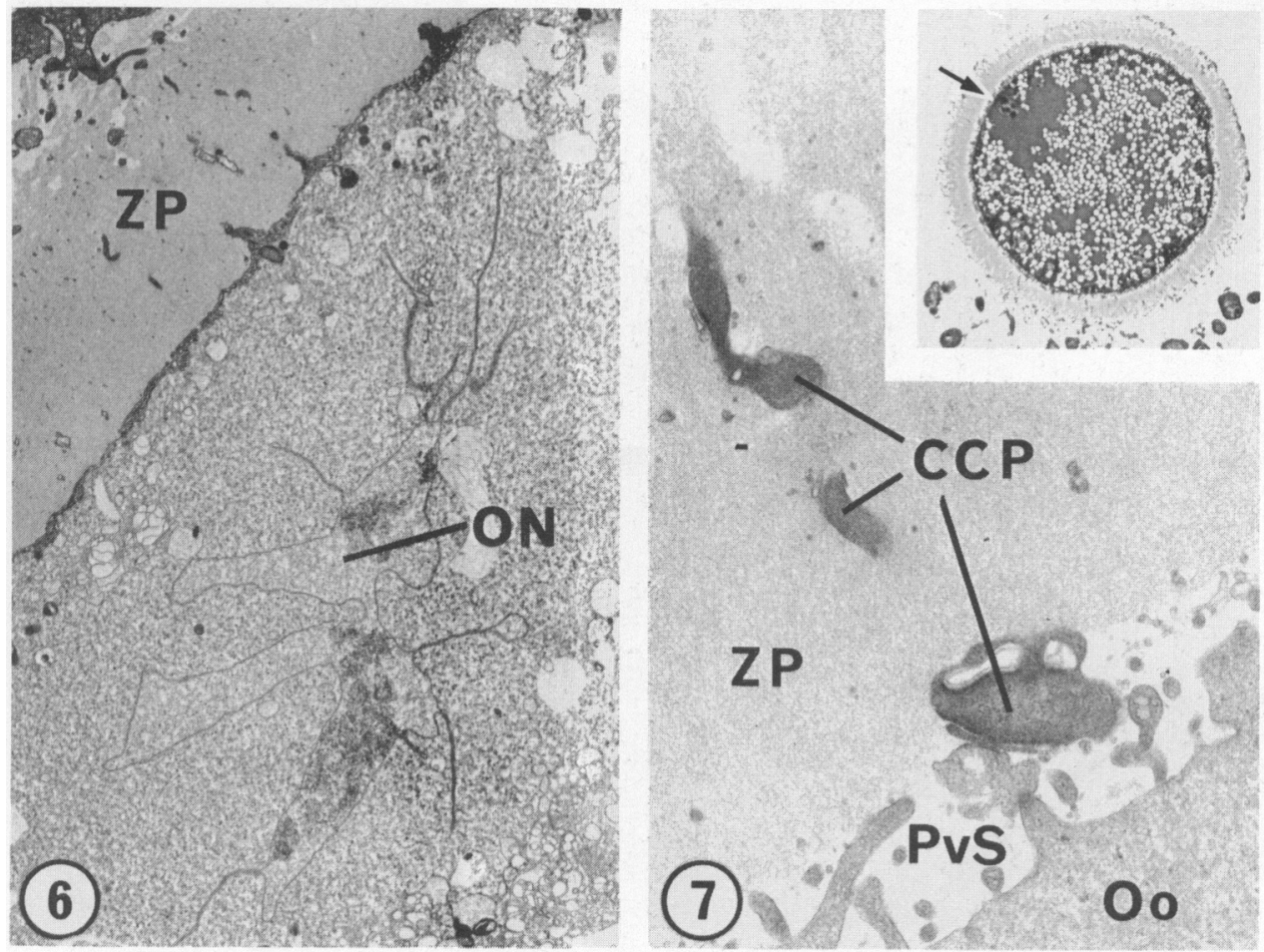

Fig. 6. Detail of type II oocyte showing the zona pellucida (ZP) and the oocyte nucleus $(\mathrm{ON})$ in the initial process of breaking down. Note the initial condensation of chromatin in the nucleus. $\times 3000$.

Fig. 7. Detail of type II oocyte showing the zona pellucida (ZP) which is traversed by a cumulus cell projection (CCP), ending in the perivitelline space (PvS) without any contact to the oocyte $(\mathrm{Oo}) . \times 14500$. Inset: A type II oocyte with condensed chromatin configurations (arrow). $\times 250$.

\section{Ultrastructure and normal cytoplasmic maturation}

Before and at the time of the LH peak. In all oocytes of type I, which were isolated before and at the time of the LH peak, the nucleus was located eccentrically in the ooplasm (Fig. 1). The cumulus cells had numerous projections which penetrated the zona pellucida and ended in invaginations of the oolemma. Junctions with a structure similar to that of the zonula adhaerens were observed between these projections and the oolemma (Fig. 5). A perivitelline space was either absent or small with a limited number of microvilli lying with their long axis parallel to the oocyte surface. Between the bases of the microvilli coated pits of $\sim 200-300 \mathrm{~nm}$ in diameter were invaginating from the oolemma and coated vesicles of similar size were located in the cortical ooplasm.

Large numbers of membrane-bounded vesicles were most frequently evenly distributed throughout the ooplasm (Fig. 1). These vesicles varied greatly in size from one oocyte to another with a maximum diameter of $\sim 10 \mu \mathrm{m}$. On some occasions aggregates of fused vesicles were observed. The mitochondria were located in clusters, predominantly peripherally (Fig. 1). Vesicles, mitochondria and some of the lipid droplets observed in the ooplasm were related to well developed cisternae of smooth endoplasmic reticulum (SER) (Figs 2 \& 3) which, on some occasions, formed big clusters peripherally. 


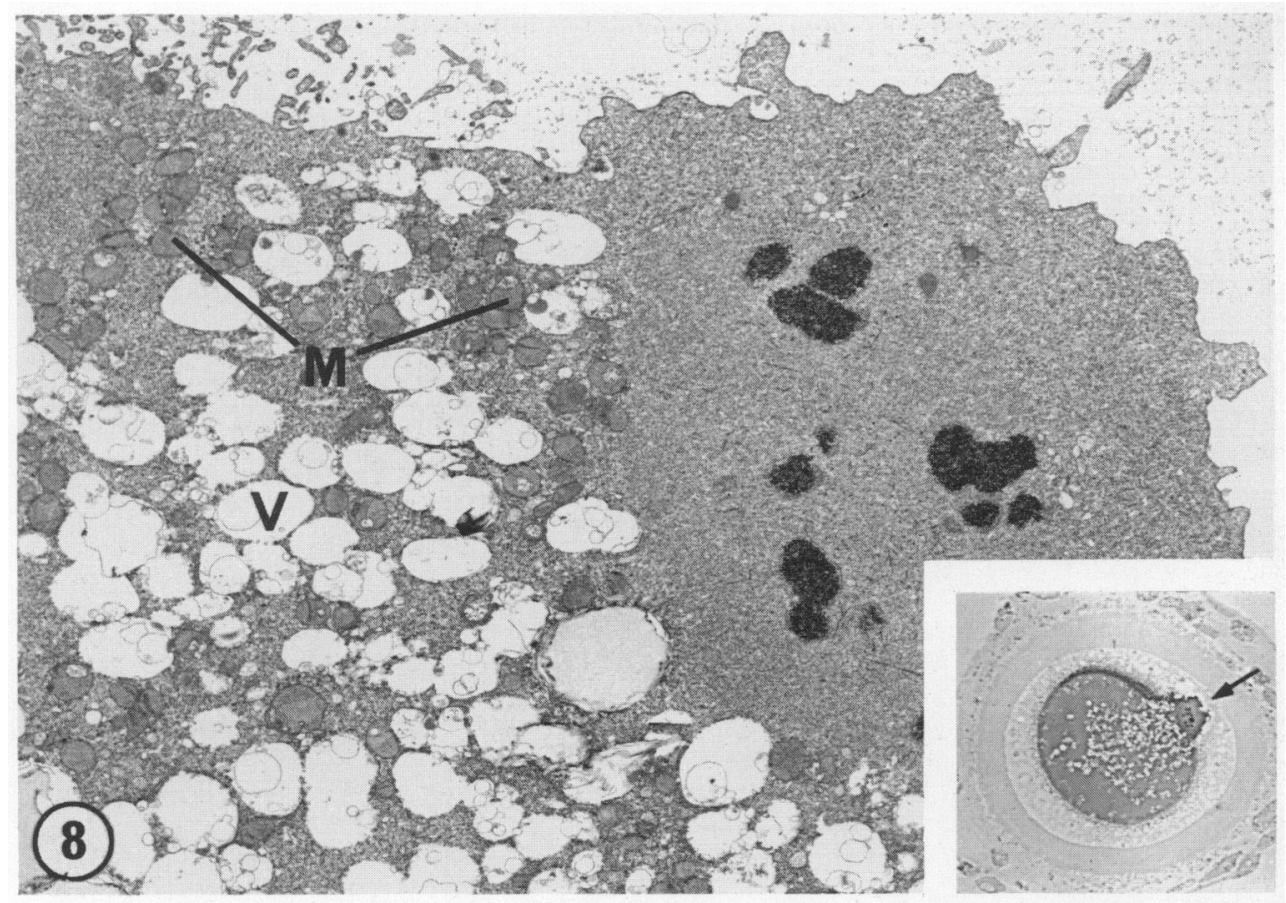

Fig. 8. Detail of a type II oocyte showing vesicles (V) and mitochondria (M) which are dislocated towards the site of polar body formation. $\times 5300$. Inset: The site of polar body formation $(\rightarrow) \times 250$.

Big clusters of cortical granules were located at the periphery of the ooplasm although the total number of cortical granules seemed to vary from one oocyte to another (Figs 1 \& 4). Well developed Golgi complexes were also located at peripheral sites. Characteristically, the cortical granules were closely related to the SER and, to some degree, to the Golgi complexes (Fig. 4).

After the time of the $\mathrm{LH}$ peak. From 0 to $2 \mathrm{~h}$ after the $\mathrm{LH}$ peak the perivitelline space was slightly enlarged, and this process continued throughout the preovulatory maturation. Concomitant with this initial increase the number of oocyte microvilli apparently increased and the microvilli became more erect.

A bout $9-12 \mathrm{~h}$ after the LH peak the oocyte nucleus was broken down. The initiation of this process was characterized by extensive convolution of the nuclear envelope and condensation of the chromatin (Fig. 6). After the oocyte nucleus breakdown condensed chromatin configurations were observed at peripheral sites in more densely packed areas of the ooplasm devoid of organelles. Concomitant with oocyte nucleus breakdown the junctions between cumulus cell projections and oolemma were disrupted (Fig. 7). In those oocytes of type II in which the nucleus was in the process of breaking down, and in another oocyte of type II from Animal 11, a certain proportion of the cumulus cell projections showed signs of degeneration and retraction. In all other oocytes of type II and all those of type III no junctions were observed.

About $15 \mathrm{~h}$ after the LH peak two major organelle rearrangements occurred in the ooplasm. The mitochondrial clusters assumed an even, spatial distribution and the vesicles appeared to be more central. During abstriction of the first polar body a second rearrangement of these organelles was noticed as they were eccentrically dislocated towards the site of polar body formation (Fig. 8). In many specimens, the polar body was surrounded by cytoplasmic droplets and cellular debris 


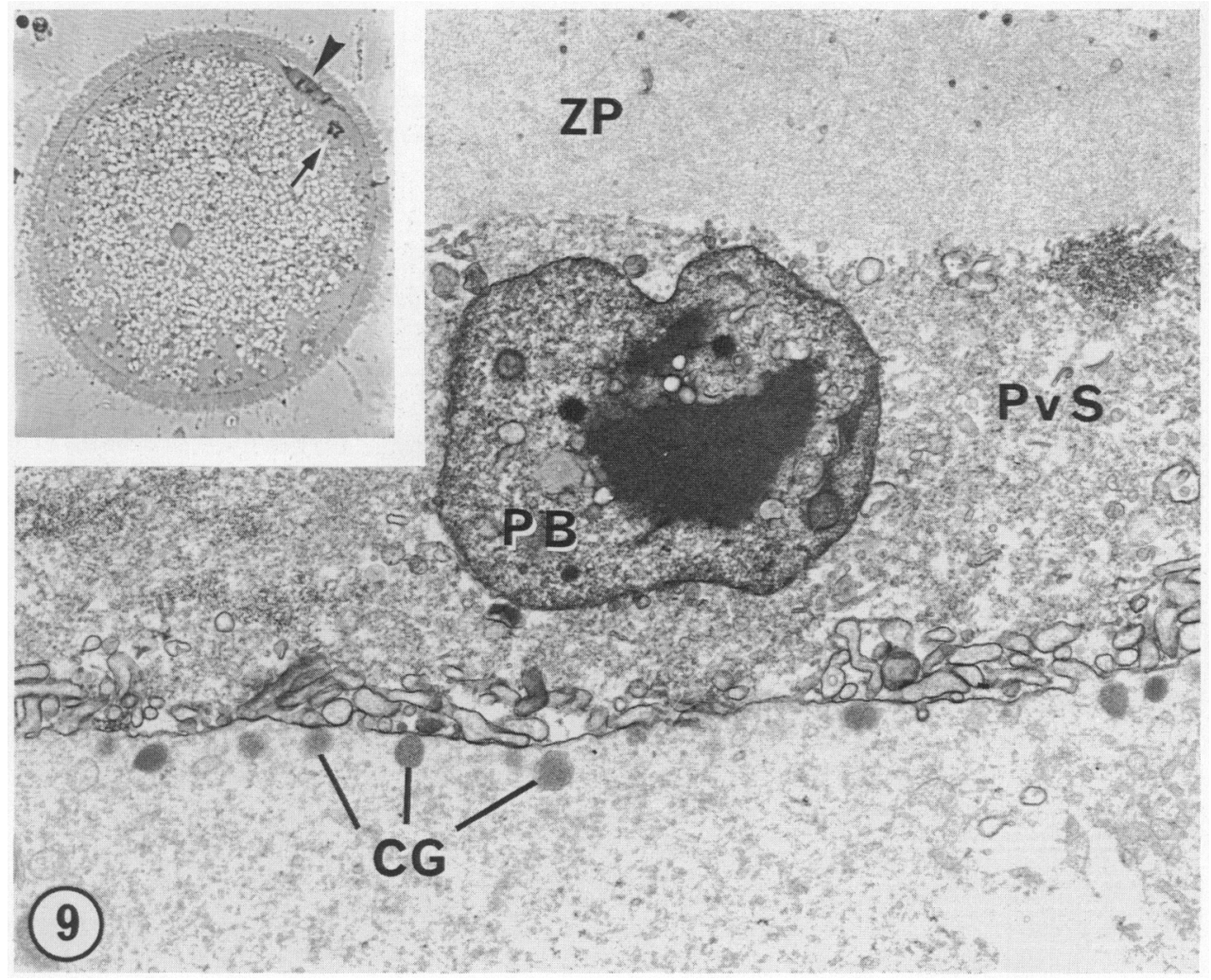

Fig. 9. Detail of type III oocyte showing zona pellucida (ZP), and the perivitelline space (PvS), in which the first polar body (PB) is located. In the oocyte the cortical granules (CG) are located in solitary positions. $\times 15500$. Inset: Type III oocyte with the first polar body $(V)$ containing condensed chromatin configurations and the oocyte also with condensed chromatin configurations at a peripheral site $(\rightarrow) . \times 250$.

containing cortical granules. Occasionally, cumulus cell projections were enlarged in the perivitelline space to sizes almost similar to that of the first polar body.

At $21-22 \mathrm{~h}$ after the $\mathrm{LH}$ peak the cortical granules were dispersed to solitary positions forming a row close to the oolemma (Fig. 9). Concomitant with this rearrangement the Golgi complexes decreased in size, the SER decreased in size or formed big clusters at peripheral sites, and the close association between mitochondria, vesicles and lipid droplets through SER was reduced.

No ultrastructural differences were noticed between oocytes collected from animals stimulated with PMSG or FSH.

\section{Ultrastructure and deviant cytoplasmic maturation}

In some oocytes the synchrony between nuclear and cytoplasmic maturation was lacking. For example, the type II oocyte aspirated from Animal 22 had completed all organelle transformations characteristic for the time in relation to the LH peak in spite of the absence of the first polar body, while no such rearrangements were observed in the type II oocyte collected from Animal 23. Similarly, the oocyte of type III aspirated from Animal 9 did not exhibit such organelle rearrangements in spite of an advanced stage of nuclear maturation. 


\section{Discussion}

The preovulatory nuclear maturation of the oocytes as well as the accompanying steroidogenic changes in the follicles, in general followed the same patterns as described for unstimulated cattle (Kruip et al., 1983; Dieleman et al., 1983) although some minor time differences were noticed. For example, Kruip et al. (1983) reported that the oocyte nucleus breakdown occurred 4-8 $\mathrm{h}$ after the LH peak while our findings suggest a later occurrence in stimulated cattle. Moreover, Dieleman et al., (1983) observed a substantial increase in the mean progesterone concentrations relative to the mean oestradiol concentrations about $20 \mathrm{~h}$ after the $\mathrm{LH}$ peak in unstimulated cattle while our present findings, supported by other data from this laboratory (Callesen et al., 1984), indicate an earlier increase in the progesterone/oestradiol ratios.

The ultrastructural observations of the oocytes aspirated before and at the time of the LH peak confirm descriptions in unstimulated cattle by Flemming \& Saacke (1972) and Kruip et al. (1983). After the LH peak a series of ultrastructural changes in the ooplasm occurred parallel to the nuclear maturation. The first change observed was the formation and enlargement of the perivitelline space as reported for unstimulated cattle (Kruip et al., 1983). Subsequently, oocyte nucleus breakdown and the concomitant disruption of the junctions between cumulus cells and oocyte occurred. It is well established that this junctional contact includes gap junctions in a number of species including cattle (Anderson \& Albertini, 1976; Epstein, Beers \& Gilula, 1976; Szöllösi, 1978; Szöllösi, Gérard, Ménézo \& Thibault, 1978) and it is possible that the functional loss of intercellular communication precedes the observed retraction and degeneration of the cumulus cell projections. A causal relationship between the loss of intercellular communication and the oocyte nucleus breakdown has been suggested (Dekel \& Beers, 1980; Dekel, Lawrence, Gilula \& Beers, 1981). However, experiments in sheep (Moor, Osborn, Cran \& Walters, 1981), pig (Gérard, Ménézo, Rombauts, Szöllösi \& Thibault, 1979) and mice (Eppig, 1982) indicate that nucleus breakdown precedes the decline in intercellular coupling. In cattle the two processes apparently occur concomitantly, and from the present observations it is impossible to establish whether this relationship is causal or not.

The close association between mitochondria, vesicles and lipid droplets through the SER in the oocyte confirms descriptions in unstimulated cattle by Flemming \& Saacke (1972) and Kruip et al. (1983) who suggested the existence of metabolic units. Mitochondrial clusters and vesicles were rearranged $\sim 15 \mathrm{~h}$ after the LH peak. Similar organelle rearrangements are reported in unstimulated cattle as taking place more than $19 \mathrm{~h}$ after the LH peak (Kruip et al., 1983). Hence, in unstimulated and stimulated cattle these major organelle rearrangements of the oocyte occur concomitant with a substantial increase in the progesterone dominance in the follicular fluid. Similar mitochondrial migrations have been reported for mice by Van Blerkom \& Runner (1984), who regarded the rearrangements as being essential for the preovulatory maturation and suggested them to be necessary for elevated concentrations of adenosine triphosphate for localized activities in the ooplasm.

The dispersal of cortical granules to solitary positions close to the oolemma taking place in the period $21-22 \mathrm{~h}$ after the $\mathrm{LH}$ peak confirms reports for unstimulated cattle (Kruip et al., 1983). In pigs this event is thought to be initiated by the cessation of communication between the cumulus cell projections and the oolemma (Szöllösi et al., 1978) while our findings indicate a different relation in cattle. The migration of the cortical granules is also regarded as being essential for preovulatory oocyte maturation (Santhananthan \& Trounson, 1982). Observations of oocytes from rat and hamster (Szöllösi, 1967), rabbit (Zamboni \& Mastroianni, 1966) and human (Baca \& Zamboni, 1967; Santhananthan et al., 1984) indicate that the cortical granules are formed in the Golgi complexes. Our findings suggest that this formation is more closely associated with certain parts of the SER than with the Golgi complexes, confirming observations of pig oocytes (Cran, 1985). The reduction of the Golgi complexes and the reduction or rearrangement of the SER combined with the dispersal of the cortical granules may reflect the termination of cortical granule formation. 
The present observations indicate a general pattern of preovulatory follicular maturation as well as of oocyte nuclear and cytoplasmic maturation in stimulated cattle. However, a certain variation or asynchrony between animals, between follicular and oocyte maturation, and even within oocytes between nuclear and cytoplasmic maturation, was noticed. Animal 1 deviated from the patterns found for all other animals with respect to follicular as well as oocyte maturation. One ovary from this animal had a 3-4-day-old corpus luteum, indicating that a premature ovulation had taken place (Greve, Callesen \& Hyttel, 1984) probably induced by the LH action of the compound used for stimulation (Allen \& Stewart, 1978; Murphy, Mapletoft, Manns \& Humphrey, 1984). However, a similar corpus luteum was found in Animal 4 without any effect on follicular or oocyte maturation. Remarkable differences between follicular and oocyte maturation were noticed in Animals 1, 9, 17, 22 and 23, suggesting the existence of a certain degree of independence between the two processes. Similarly, Rüsse (1982) found cattle with tubal oocytes in which the first polar body had not been abstricted. Asynchrony within oocytes between nuclear and cytoplasmic maturation was present in Animals 9 and 22, each of which yielded oocytes in which the spatial arrangement of the organelles was in conflict with the state of nuclear maturation.

It is likely that these different degrees of asynchrony, each of which affects the normal patterns of follicular and/or oocyte maturation, are all causally involved in the highly unpredictable results of the current regimens used for superovulation.

We thank Dr B. Svenstrup, Statens Seruminstitut, Copenhagen, Denmark, and Dr A. Madej, Department of Clinical Chemistry, Swedish University of Agricultural Sciences, Uppsala, Sweden, for the supply of oestradiol-17ß antiserum and LH antibodies, respectively. The work was supported by grant number 5.10.17.06 and 13-3641 from the Danish Agricultural and Veterinary Research Council.

\section{References}

Allen, W.R. \& Stewart, F. (1978) The biology of pregnant mare serum gonadotrophin (PMSG). In Control of Reproduction in the Cow, pp. 50-72. Ed. J. M. Sreenan. M. Nijhoff, The Hague.

Anderson, E. \& Albertini, D.F. (1976) Gap junctions between the oocyte and companion follicles cells in the mammalian ovary. J. Cell Biol. 71, 680-686.

Baca, M. \& Zamboni, L. (1967) The fine structure of human follicular oocytes. J. Ultrastruct. Res. 19, 354-381.

Bomsel-Helmreich, O., Gougeon, A., Thibault, A., Saltarelli, D., Milgrom, E., Frydman, R. \& Papiernik, E. (1979) Healthy and atretic human follicles in the preovulatory phase: differences in evolution of follicular fluid. J. clin. Endocr. Metab. 48, 686-694.

Callesen, H., Greve, T. \& Hyttel, P. (1984) Follicular steroids and ovarian development in superovulated dairy cattle. A preliminary report. J. In Vitro Fertilization \& Embryo Transfer 1, 101, Abstr.

Cran, D.G. (1985) Qualitative and quantitative structural changes during pig oocyte maturation. J. Reprod. Fert. 74, 237-245.

Dekel, N. \& Beers, W.H. (1980) Development of the rat oocyte in vitro: inhibition and induction of maturation in the presence or absence of the cumulus oophorus. Devl Biol. 75, 247-254.

Dekel, N., Lawrence, T.S., Gilula, N.B. \& Beers, W.H. (1981) Modulation of cell-to-cell communication in cumulus oocyte complex and the regulation of oocyte maturation by LH. Devl Biol. 85, 358-362.
Dieleman, S.J., Kruip, Th. A.M., Fontijne, P., de Jong, W.H.R. \& van der Weyden, G.C. (1983) Changes in oestradiol, progesterone and testosterone concentrations in follicular fluid and in the micromorphology of preovulatory bovine follicles relative to the peak of luteinizing hormone. J. Endocr. 97, 31-42.

Emment, Y., Collins, W.P. \& Sommerville, I.F. (1972) Radioimmunoassay of oestrone and oestradiol in human plasma. Acta endocr., Copenh. 69, 567-582.

Eppig, J. (1982) The relationship between cumulus cell oocyte coupling, oocyte mejotic maturation and expansion. Devl Biol. 89, 268-272.

Epstein, M.L., Beers, W.H. \& Gilula, N.B. (1976) Cell communication between the rat cumulus oophorus and the oocyte. J. Cell Biol. 70, 301, Abstr.

Flemming, W.N. \& Saacke, R.G. (1972) Fine structure of the bovine oocyte from the mature Graafian follicle. J. Reprod. Fert. 29, 203-213.

Gérard, M., Ménézo, Y., Rombauts, P., Szöllösi, D. \& Thibault, C. (1979) In vitro studies of oocyte maturation and follicular metabolism in the pig. Annls Biol. anim. Biochim. Biophys. 19, 1521-1535.

Greve, T., Callesen, H. \& Hyttel, P. (1984) Plasma progesterone profiles and embryo quality in superovulated dairy cows. Theriogenology 21, 238, Abstr.

Hoffmann, B., Kyrein, H.J. \& Ender, M.L. (1973) An efficient procedure for the determination of progesterone by radioimmunoassay applied to bovine peripheral plasma. Hormone Res. 4, 302-310. 
Ireland, J.J. \& Roche, J.F. (1983) Development of nonovulatory antral follicles in heifers: changes in steroids in follicular fluid and receptors for gonadotrophins. Endocrinology 112, 150-156.

Jensen, A.M., Greve, T., Madej, A. \& Edqvist, L.-E. (1982) Endocrine profiles and embryo quality in the PMSG-PGF ${ }_{2} \alpha$ treated cow. Theriogenology 18, 33-44.

Kruip, T.A.M., Cran, D.G., van Beneden, T.H. \& Dieleman, S.J. (1983) Structural changes in bovine oocytes during final maturation in vivo. Gamete Res. 8, 29-47.

McNatty, K.P., Moore Smith, D., Osathanondh, R. \& Ryan, K.J. (1979) The human antral follicle: functional correlates of growth and atresia. Annls Biol. anim. Biochim. Biophys. 19, 1547-1558.

Moor, R.M. \& Warnes, G.M. (1979) Regulation of meiosis in mammalian oocytes. Br. med. Bull. 35, 99-103.

Moor, R.M., Osborn, J.C., Cran, D.G. \& Walters, D.E. (I981) Selective effects of gonadotrophins on cell coupling, nuclear maturation and protein synthesis in mammalian oocytes. J. Embryol. exp. Morph. 61, $347-365$.

Murphy, B.D., Mapletoft, R.J., Manns, J. \& Humphrey, W.D. (1984) Variability in gonadotrophin preparations as a factor in the superovulatory response. Theriogenology 21, 117-125.

Rüsse, I. (1982) Morphological changes of the bovine egg cell during ovulation. Zentbl. VetMed. C 11, 365, Abstr.

Santhananthan, A.H. \& Trounson, A.O. (1982) Uitrastructural observations on cortical granules in human follicular oocytes cultured in vitro. Gamete Res. 5, 191-198.
Santhananthan, A.H., Ng, S.E., Chia, C.M., Law, H.Y., Edirisinghe, W.R. \& Ralnam, S.S. (1984) The origin and distribution of cortical granules in human follicular oocytes $J$. In Vitro Fertilization \& Embryo Transfer 1, 136, Abstr.

Solti, L., Greve, T. \& Koefoed-Johnsen, H.H. (1978) Plasma progesterone in superovulated cattle. Acta vet. scand. 19, 298-309.

Stupnicki, R. \& Madej, A. (1976) Radioimmunoassay of LH in blood plasma of farm animals. Endokrinologie 68, 6-13.

Szöllösi, D. (1967) Development of cortical granules and the cortical reaction in rat and hamster eggs. Anat. Rec. 159, 431-446.

Szöllösi, D. (1978) On the role of gap junctions between follicle cells and oocyte in the mammalian ovarian follicle. Res. Reprod. 10, 3-4.

Szöllösi, D., Gérard, M., Ménézo, Y. \& Thibault, C. (1978) Permeability of ovarian follicles; corona celloocyte relationship in mammals. Annls Biol. anim. Biochim. Biophys. 18, 511-521.

Van Blerkom, J. \& Runner, M.N. (1984) Mitochondrial reorganization during resumption of arrested meiosis in the mouse oocyte. Am. J. Anat. 171, 335-355.

Zamboni, L. \& Mastroianni, L. (1966) Electron microscopic studies on rabbit ova. I. The follicular oocyte. J. Ultrastruct. Res. 14,95-117.

Received 3 July 1985 